\title{
高密度アレー観測記録に基づく応答スペクトル比の確率分布 DETERMINATION OF SPATIAL DISTRIBUTION OF RESPONSE SPECTRAL RATIOS FROM DENSE ARRAY DATA
}

\author{
川上英二*1, 茂木秀則*2 \\ Hideji KAWAKAMI and Hidenori MOGI
}

\begin{abstract}
Acceleration response spectral ratios were analyzed to examine their statistical characteristics. First, the probability distribution of the ratios was analyzed, and equations for the probability density functions, mean values, standard deviations, and percentiles were shown. Second, the above-mentioned statistics were estimated using accelerometer arrays of the Chiba and SMART-1 databases. Then, the relationships between these statistics and the station separations, frequencies and damping ratios were analyzed. Finally, based on the $50^{t h}$ and $95^{\text {th }}$ percentiles, the differences between the response spectra at two different sites due to future earthquakes were discussed.
\end{abstract}

Keywords: response spectra, probability density, lognormal distribution, dense array database 応答スペクトル, 確率密度, 対数正規分布, 高密度アレー

1 はじめに

地震被害の検討や耐震設計は最大加速度や応答スペクトルなど の地震動の強度指標に基づいて行われることが多い。この理由と して, 複雑な地震動波形を扱わずに, 地震動波形の最大值, ある いは構造物の特性を反映した応答波形の最大值（応答スペクトル） など, 単一の数值によって設計や検討が可能となる利便性が挙げら れる.

ところで, 同一地震による極めて近い二点における地震動でも 決して同じものではない。このため, 隣接した観測点やアレー観 測における地震記録から最大加速度や最大速度, コヒーレンスな

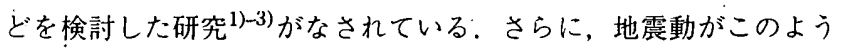
に確率的な要素を伴うために, 地震動の強度指標も確率変数とし ての扱いが必要となる。このことから, 酎震設計の方法として信 頼性解析 ${ }^{4)}$ に基づく方法がよく用いられる。信頼性解析では, 地震 外力と構造物の地震酎力の確率分布に基づいて, その大小関係か ら破壊確率が評価されるため, 構造物の地震耐力だけでなく地震 外力の確率分布, 特にその散布度（ばらつき）が重要な意味を持っ ている. 例えば, 同一設計の構造物が隣接し, それぞれの地震被 害の程度が異なる場合には構造物の地震耐力の確率分布, 特に地 震耐力の平均值と散布度が問題となるが, 地震耐力の散布度を検 討するためには地震外力の散布度を予め把握している必要がある. また，長大構造物の設計においては，想定される平均的な地震動
強度に地震動の空間分布特性を加味した地震外力を作用させる必 要があるが, この場合, 構造物に沿った地震動の位相の分布特性と 共に, 最大加速度や応答スペクトルなどの空間分布も考慮するこ とで，より合理的な耐震設計が可能になると考えられる。

地震動強度指標の散布度を検討している研究として, 最大加速 度や応答スペクトルなどの地震動強度の距離減衰式とともにその 確率分布 ${ }^{5)-7)}$ を求めた統計的な研究や, 応答スペクトルの平均值や

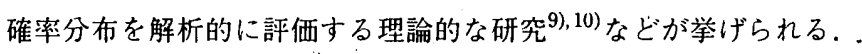
しかし,これらの統計的な研究では, 推定された地震動強度指標か らの誤差の確率分布が論じられており，「同一の地震に対してある 領域で生じ得る地震動強度指標の差異」という意味とは異なった散 布度が評価されている。また，観測記録か.ら直接，上記の「差異」 を評価した研究は著者の知る限り存在しない。

このことから, 著者らは地震動の強度指標として最大加速度を 取り上げ，その空間的な確率分布について, 高密度アレーや地震動 モニタリングシスデムの観測記録を用いて最大加速度の比（最大 加速度比）の統計解析を行った ${ }^{11), 12)}$. その結果最大加速度は, 数 十 $\mathrm{m}$ 離れた二点においても最大で（95\%の確率で）互いに0.7 $1 . \dot{4}$ 倍程度の範囲の違いまで観測され得ること, 数 $\mathrm{km}$ 離れた二点 では 0.2 -5 倍程度の範囲の違いまで観測され得ること, 二点間の 距離の対数值の增加に伴い最大加速度比の（対数）標準偏差が線 形的に增加することなどを明らかにしている．また；著者らによっ
*1 埼玉大学地圈科学研究センター 教授. 工博

*2 埼玉大学工学部建設工学科 講師. 博士 (工学)
Prof., Geosphere Research Institute, Saitama Univ., Dr. Eng.

Lecturer, Dept. of Civil and Environmental Engineering, Saitama Univ., Dr. Eng. 
て，加速度応答スペクトルの場合についても同様に，比を用いた 検討が行われている ${ }^{13)}$. しかし，この研究では，マグニチュードや 震央距離など様々なパラメータが応答スペクトル比に与える影響 を多変量解析によって評価することを主たる目的としており，応答 スペクトルの確率分布とそれを特徽付ける代表值, 散布度などの 統計量そのものの評価という目的からは不十分である.

以上のことから本研究では, 最大加速度に対して展開された半 区間対数正規分布に基づく統計解析の方法を応答スペクトル比（同 一地震による二点での地震動の応答スペクトルの比）に適用し，二 点間の距離, 振動数, 減衰比をパラメータとして, 応答スペクトル 比の代表值, 散布度, \%位值などの特性値や確率密度関数を評価し た。そしてこれらの特性值に基づいて, 離れた二点において想定 される応答スペクトルの差異について論じた。

地震動は地震規模, 震源距離, 断層との位置関係, 観測点の地 盤構成等の物理的要因や波動の周期などによって影響を受け, 極め て近い観測点間の地震動でも，互いに著しい差異が認められる場合 がある. 例えば, 観測点近傍の地盤条件は測定が可能であり, 顕著 な不整形が認められる場合には, 地震動強度の違いを物理的要因 の違いに基づいて波動論的に考察することは重要である。しかし， 現在でも測定が困難な要因が多く考えられる. 例えば, 震源に対す る観測点の僅かな方位の違いに伴う放出波形の違い，震源から観測 点に至るパスの全経路に沿った地盤物性の詳細な違いなどであり, これらの原因によっても応答スペクトルが強く支配されているも のと考えられる。将来, これらの物理量が余すところなく測定で きる場合には，各地点に扔ける応答スペクトルの值が全て説明し 得るようになることも考えられる。しかし，実際本論文の 4 章， 5 章で示すように，現在観測できる物理量から見た場合には不整形性 が小さい(明らかでない) と考えられる千葉と SMART-1の二つの 各アレー内においても，応答スペクトルの比較的大きい違いが観測 されている。この違いを観測されている物理量だけから説明する ことは難しく，この違いの程度に関する統計量を検討することは重 要であると考えられる。このことから本研究では, 地震動の場所 による変動を確率分布で定量的に提示することを目的としている.

本研究で用いたアレー観測記録は二つのアレーで 48 地震の観測 記録であり十分に多い数ではないが, 二点間距離などの関数とし て連続的な結果が得られており, 整形地盤とみなせる地盤における 応答スペクトルのばらつきの一般的な傾向は評価できているもの と考えられる.ただし, 近地の大地震のデータが欠けているため, このような地震に伴う応答スペクトルのばらつきを本研究の結果 から論じるには注意が必要である。

\section{2 解析手法 ${ }^{11-13)}$}

\section{1 応答スペクトル比の定義}

本研究では，二地点間で観測される応答スペクトルの違いを示 す值として, 同一地震による任意の二観測点における地震動の応 答スペクトルの比（応答スペクトル比）を考え，比を求める二点間 の距離 (二点間距離), 振動数, 隇衰比をパラメータとして統計解 析を行った.

応答スペクトル比 $R$ は応答スペクトルの大きい方を常に分母 とするものと定義し, $0<R \leq 1$ の範囲の值をとるものとする. この定義から, 応答スペクトル比が 1 の近くに分布する場合には 応答スペクトルの散布度が低く, 応答スペクトル比が小さい範囲ま で分布が及ぶ程応答スペクトルの散布度が高いことを表している。

\section{2 芯答スペクトル比の確率分布と特性值}

本節では, 記号の定義と応答スペクトルの統計的なモデル化を 明らかにすることを目的に，文献 11)，12）に示した定式化の要点 を示す。

片山らは応答スペクトルの実測值と距離減衰式の比の確率分布 を対数正規分布に近似し，この近似が妥当であることを $\chi^{2}$ 検定に よって示している7). また, McGuire も疑似速度応答スペクトルの 実測値と距離減衰式による推定值の比の確率分布が対数正規分布 に従うものとしている ${ }^{8)}$. 本研究では隣接する二点の組合せにおい て同一地震で生じる応答スペクトルの違いを検討しており，このよ うな二点の震央距離の違いは殆どなく, 応答スペクトルの推定値は アレー内の全ての点で同一の值と見做すことができる。このため， 応答スペクトルの実測值と距離隇衰式による推定值との比が対数 正規分布する場合には，応答スペクトルそのものも対数正規分布 に従うものと考えてよい.

上記のことから本研究では,

- 任意の地点の地震動強度（応答スペクトル）分布は対数正規 分布であること，

- 比をとる二点は同一の地震動強度が期待される二点，すなわ ち同一の対数正規分布（平均と分散が同一）を有する二地点 であること，

を仮定し, 比を求める二点の応答スペクトルの対数値 $Z_{1}, Z_{2}$ の 同時確率密度関数を次の二次元正規分布の同時確率密度関数 ${ }^{14)}$ で 表す.

$$
\begin{array}{r}
f_{Z_{1}, Z_{2}}\left(z_{1}, z_{2}\right)=\frac{1}{2 \pi \sigma_{Z}^{2} \sqrt{1-\rho^{2}}} \exp \left[-\frac{1}{2 \sigma_{Z}^{2}\left(1-\rho^{2}\right)}\right. \\
\left.\cdot\left\{\left(z_{1}-\mu_{Z}\right)^{2}-2 \rho\left(z_{1}-\mu_{Z}\right)\left(z_{2}-\mu_{Z}\right)+\left(z_{2}-\mu_{Z}\right)^{2}\right\}\right]
\end{array}
$$

ここで, $\rho, \mu_{Z}, \sigma_{Z}$ はそれぞれ, $Z_{1}, Z_{2}$ の相関係数, 平均值, 標準偏差である.

式 (1) から応答スペクトル比 $R$ の確率密度関数を求めると次式 が得られる ${ }^{11), 12)}$

$$
\begin{aligned}
& f_{R}(r)=\frac{2}{\sqrt{2 \pi} \sigma_{P^{\prime}} r} \exp \left(-\frac{\ln ^{2} r}{2 \sigma_{P^{\prime}}^{2}}\right), 0<r \leq 1 \\
& \sigma_{P^{\prime}}=\sigma_{Z} \sqrt{2(1-\rho)}
\end{aligned}
$$

ここで, $P^{\prime}$ は $Z_{1}, Z_{2}$ の差 $P^{\prime}=Z_{1}-Z_{2}$ であり，応答スペク トル比 $R$ は $R=\exp \left(-\left|P^{\prime}\right|\right)$ で表される. 式 (2) に示されるよ うに, 確率密度関数には地震ごとの平均值 $\mu_{Z}$ が含まれない. 従っ て，同一地震ごとに応答スペクトルの比を求める限り，地震ごとに 異なる平均值 $\mu_{Z}$ を評価する必要がないという利点がある. 本研 究では, 確率密度関数が式 (2)に示される確率分布を半区間対数正 規分布と呼ぶ ${ }^{12)}$.

応答スペクトル比 $R$ の平均値 $\mu_{R}$ は式 (2) から次式のように 求められる.

$$
\mu_{R}=\exp \left(\frac{\sigma_{P^{\prime}}^{2}}{2}\right)\left\{1-\operatorname{Erf}\left(\frac{\sigma_{P^{\prime}}}{\sqrt{2}}\right)\right\}
$$

ここで, $\operatorname{Erf}(\cdot)$ は䛊差関数である. 式 (2)(4)、に示されるように, 標 準偏差 $\sigma_{P^{\prime}}$ が応答スペクトル比 $R$ の確率分布の唯一のパラメー タであり, 応答スペクトル比の平均值 $\mu_{R}$ も標隼偏差 $\sigma_{P^{\prime}}$ と同 様に，応答スペクトルの散布度を表す特性値の一つである ${ }^{11), 12)}$. 


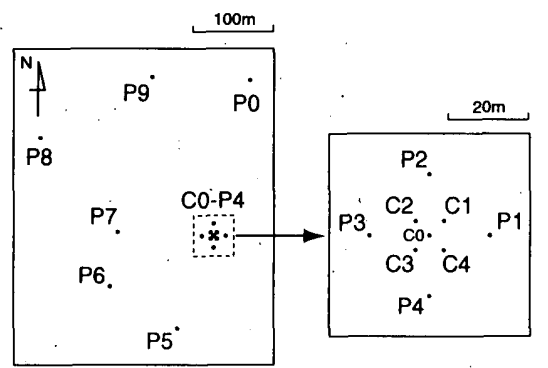

図 1 千葉アレーの平面図 ${ }^{15)}$

応答スペクトル比の\%位值を, 応答スペクトル比 $R$ が $1 \geq$ $R \geq r_{\gamma}>0$ の範囲にある確率が $\gamma \%$ であるときの値 $r_{\gamma}$ と定義 する。このとき\%位值は次式で算定される：

$r_{\gamma}=\exp \left(-\tau_{\gamma} \sigma_{P^{\prime}}\right), \quad \frac{\gamma}{100}=\int_{-\tau_{\gamma}}^{\tau_{\gamma}} \frac{1}{\sqrt{2 \pi}} \exp \left(-\frac{t^{2}}{2}\right) d t$

3 アレー観測記録の概要

3.1 千葉アレー ${ }^{15)}$

\subsection{1 アレー施設の概要}

本アレー記録は東京大学生産技術研究所千葉実験所構内の三次

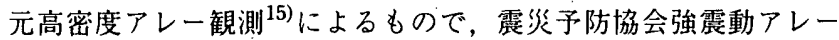
観測記録データベースに蒐集されている．本研究では簡単のため， このアレーを「千葉ア・レー」と略記する。

図1に千葉アレーの平面図を示す。千葉アレーは 1982 年から 観測が開始され，当初は $\mathrm{C} 0 \sim \mathrm{C} 4, \mathrm{P} 1 \sim \mathrm{P} 6$ の 11 点（地中埋設分 を含めると 36 点）で観測が行われていた。1985年から P7-P9, $\mathrm{P} 0$ の 4 点が新たに設置され，現在 15 点（地中埋設分を含めると 44 点) で観測が行われている.

$\mathrm{C} 0 ， \mathrm{P} 5$ －P9，P0の柱状図 ${ }^{15)}$ によれば，地盤は地表面から深さ約 $10 \mathrm{~m}$ までの $\mathrm{N}$ 值 10 以下の層とそれ以深の $\mathrm{N}$ 值 30 以上の層から構 成されている。この特徵はアレ一内の観測点に共通するものであ り,・地盤構造は平行成層構造を成している。本アレーにおけるサン プリングレートは $200 \mathrm{~Hz}$ である。

\subsection{2 地震記録の概要}

図 1 に示す $\mathrm{C} 0$ - C4, P0 P9のすべての観測孔において，地下 $1 \mathrm{~m}$ に加速度計が設置されており，本研究ではこの深度における地 震記録を地表面における記録と考え，これらを用いて検討を行った。

後述するように，本研究では半数以上の観測点で鉛直成分の最大 加速度が $10 \mathrm{~cm} / \mathrm{s}^{2}$ 以上の地震の観測記録を用いるもものとした。記 録中の最大加速度は $400.0 \mathrm{~cm} / \mathrm{s}^{2}$ (1987 年千葉県東方沖地震, M6.7, 震央距離 $45 \mathrm{~km}$ ），また，最大のマグニチュードは 7.3 （震央距離 $373 \mathrm{~km}$ )，最小のマグニチュードは 3.9 (震央距離 $38 \mathrm{~km}$ ) である.

\subsection{SMART-1 アレー ${ }^{16)-20)}$}

\subsection{1 アレー施設の概要}

SMART-1 アレーは 1980 年から 1982 年にかけて台湾・羅東に 設置されたアレー観測システムである，図 2 に示すように，地震 計は $\mathrm{C} 00$ を中心として半径 $200 \mathrm{~m} ， 1,000 \mathrm{~m} ， 2,000 \mathrm{~m}$ の同心円上 にそれぞれ 12 箇所ずつ設置されている。また， $\mathrm{C} 00$ から $2,800 \mathrm{~m}$ ， $4,800 \mathrm{~m}$ 南方に 2 つの地震計 E01，E02 が設置されている.

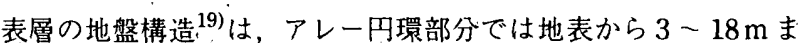
での S 波速度 120 ～ $160 \mathrm{~m} / \mathrm{s}$ の層と深さ $30 － 60 \mathrm{~m}$ までの $\mathrm{S}$ 波速度 $190 \sim 360 \mathrm{~m} / \mathrm{s}$ の層の二層からなる沖積層，さらに，それ以深の層 厚 $170 － 540 \mathrm{~m}$ の洪積層（S 波速度 $700 － 850 \mathrm{~m} / \mathrm{s} ）$ 加構成され

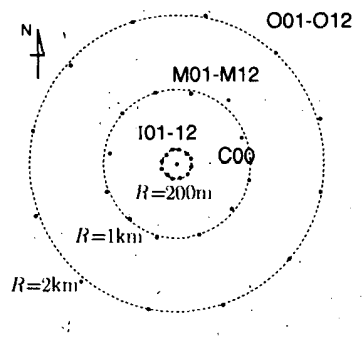

E01

- E02

図 2 SMART-1 アレーの平面図 ${ }^{16), 20)}$

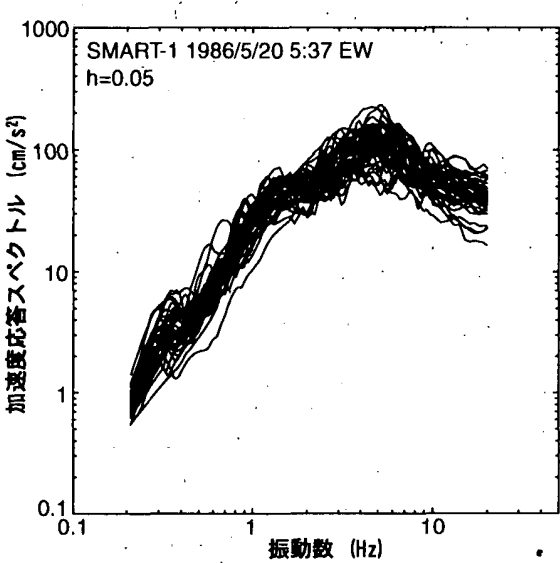

図 3 同一地震に対する加速度応答スペクトルのばらつきの例 (SMART-1 アレー，1986/5/20 5:37, EW 成分, 減衰比 $h=0.05$ )

ている，東西断面についてはほほ水平な成層構造を成しているが， 南北断面では洪積層の上面が傾斜しており，E02の南側で洪積層 が地表に現れている。このため，E02の観測記録を除外して統計解 析を行った。また，本アレー記録のサンプリングレートは $100 \mathrm{~Hz}$ である。

\section{2 .2 地震記録の概要 ${ }^{20}$}

千葉アレーの場合と同様に，アレーの半数以上の観測点におい て鉛直成分の最大加速度が $10 \mathrm{~cm} / \mathrm{s}^{2}$ 以上の 24 地震を用いて統計 解析を行った。これらの地震は 1980 年 10 月 14 日から 1986 年 11 月 14 日までに観測されたものである。記録地震にはマグニチュー ド $M_{L} 6$ 程度の地震が多く含まれており ${ }^{20)}$ ，千葉アレ一の観測記 録と比べて，最大加速度が大きい記録が比較的多い。観測記録中 の最大加速度は $375 \mathrm{~cm} / \mathrm{s}^{2}\left(\mathrm{M}_{L} 6.5\right.$, 震央距離 $\left.22 \mathrm{~km}\right)$, 最大マグ ニチュードは 7.0 (震央距離 $79 \mathrm{~km}$ )，最小マグニチュードは 3.6 （震央距離 $3 \mathrm{~km}$ ) である。

\section{4. 応答スペクトル比の分布}

\section{1 応答スペクトルの算定}

広い振動数帯域の応答スペクトルを精度良く求めるため，以下 の点に留意して応答スペクトルを算定した。まず，千葉アレーと SMART-1 アレーは共に AD 変換器のビット数が少なく，かつ強震 観測を目的とするため，小さい振幅の地震動の場合に記録の精度 が相対的に低いものとなる。このため，両アレーともに鉛直動成 分の観測記録の半数以上で $10 \mathrm{~cm} / \mathrm{s}^{2}$ 以上の最大加速度が観測さ れていることを記録地震の採否の基準として設けた。また，一部 
(a) $1 \mathrm{~Hz}$

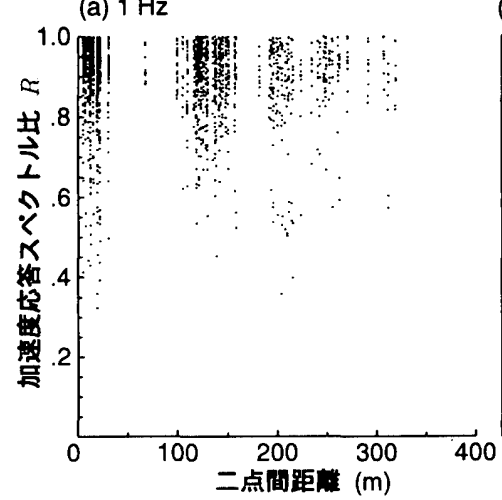

(b) $3 \mathrm{~Hz}$

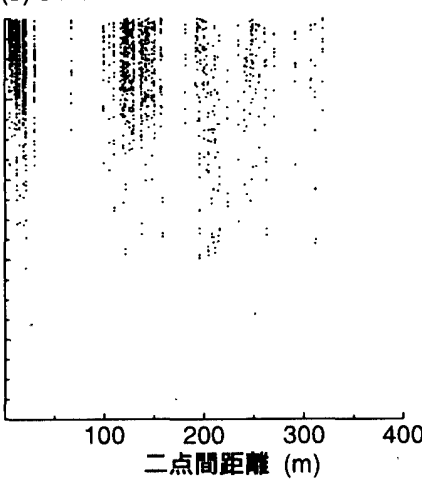

(c) $10 \mathrm{~Hz}$

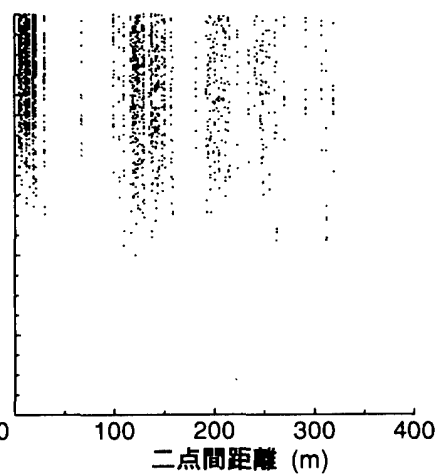

図 4 千葉アレーにおける加速度応答スペクトル比の分布 (減衰比 $h=0.05, \mathrm{EW}$ 成分)

(a) $1 \mathrm{~Hz}$

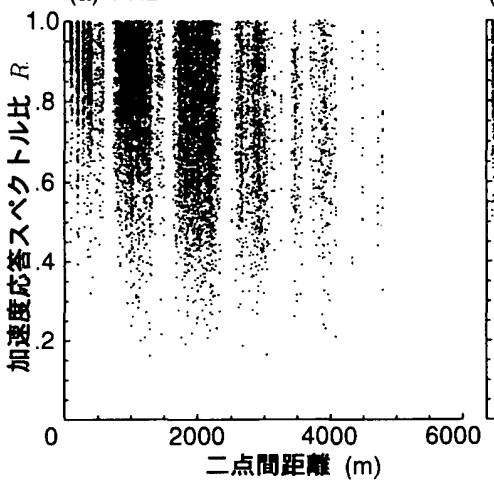

(b) $3 \mathrm{~Hz}$

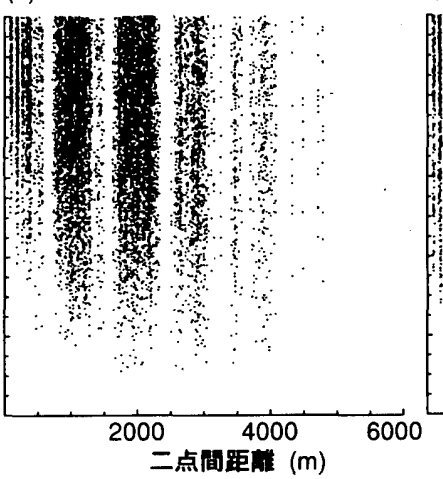

(c) $10 \mathrm{~Hz}$

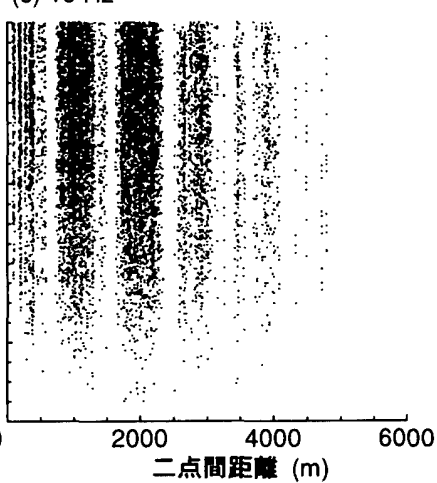

図 5 SMART-1 アレーにおける加速度応答スペクトル比の分布 (減衰比 $h=0.05, \mathrm{EW}$ 成分)

の記録では波形のオフセットなどの低振動数成分のノイズが含ま れているため, $0.2-0.3 \mathrm{~Hz}$ で低振動数成分を遮断するチェビシェフ フィルタ ${ }^{21)}$ に通した後に応答スペクトルを求めた. 統計解析を行っ た振動数は $0.5 \mathrm{~Hz} \sim 15 \mathrm{~Hz}$ の範囲の 13 振動数, また, 減衰比 $h$ は $0.01,0.03 ， 0.05,0.1,0.2$ の 5 通りである.

図 3 に，同一アレー内で見られる加速度応答スペクトルのばら つきの例として, SMART-1 アレーにおける 1986 年 5 月 20 日 5 時 37 分, $M_{L} 6.2$, 震央距離 $71 \mathrm{~km}$ の地震の加速度応答スペクト ルを示す. SMART-1 アレーの領域はそ机ほど大きいものではない にも拘わらず，図 3 に示すように応答スペクトルは各振動数で 4 5 倍程度の範囲に分布しており，その散布度は決して小さいとは言 えない。また，スペクトルの対数值はほほ同じ幅で分布すること， ただし，スペクトルピークを与える $5 \mathrm{~Hz}$ 以上ではごくわずかなが ら分布範囲が広くなる傾向が窥われることなども指摘できる。こ の傾向に関しては $5.2 て ゙$ 詳しく述べる。

\section{2 芯答スペクトル比の算定と二点間距離グループの導入}

図 4, 図 5 に減衰比 $h=0.05$ に対する千葉アレーと SMART-1 アレーの EW 成分の加速度応答スペクトル比の分布を示す. 横軸 は二点間距離 $L$ である.

図 4 を見ると, 千葉アレーにおける二点間距離が数十 $\mathrm{m}$ の場合 のように極めて近い二点においても, $0.3(1 \mathrm{~Hz}) \sim 0.5(10 \mathrm{~Hz})$ の ような小さい值を示すことがあり，応答スペクトルが非常に大きい 散布度を示すことがわかる．また，デー夕数があまり多くない千葉 アレー（図 4) ではあまり明瞭に見ることはできないが, SMART-1 アレーの場合（図 5）では $1 ， 3 ， 10 \mathrm{~Hz}$ と振動数が変化するにつ れて, 応答スペクトル比の最小值がより小さい值を示しており，振
動数が応答スペクトル比の散布度に与える影響が窅われる。

一方，二点間距離の変化に対する応答スペクトル比の分布の変 化については, 二点間距離の值によってデータ数の偏りが大きいこ と, さらに応答スペクトル比の散布度が非常に大きいこになどか ら，散布図を一見しただけでその統計的な性質を把握することは 難しい. 本研究では, このようなアレー内の地震計の配置に伴う デー夕数の偏り（二点間距離の分布）を考慮して, 表 1 , 表 2 に 示すように，千葉アレーでは 3 グループ, SMART-1 アレーでは 5 グループに分割し，それぞれのグループ内では応答スペクトル 比が同じ確率分布に従うものとして, 平均值 $\mu_{R}$, 標準偏差 $\sigma_{P^{\prime}}$ などの統計量を算定した。

\section{5 加速度応答スペクトル比の平均值 $\mu_{R}$ と標準偏差 $\sigma_{P^{\prime}}$ ，}

\section{1 二点間距離の影響}

図 6 に減衰比 $h=0.05$ の場合の加速度応答スペクトル比の平 均值 $\mu_{R}$ と標準偏差 $\sigma_{P^{\prime}}$ を示す. 横軸は各グループごとの二点 間距離の単純平均である. 図 6 から, 検討を行ったすべての振動 数において, 二点間距離の増加に対し平均值 $\mu_{R}$ が隇少。標準偏 差 $\sigma_{P^{\prime}}$ が増加する傾向を示すことがわかる. そしてこの傾向は, 若干の不連続性は見られるものの, 条件が大きく異なる二つのア レーに共通の連続的な関係と言える。

この二点間距離の増加に対する応答スペクトル比の散布度の増 加は, 式 (2)(3) に基づいた場合, 二点の応答スペクトルの对数值の 相関係数 $\rho$ の減少によるものと考えることができる. 図 6 に示さ れる標準偏差 $\sigma_{P^{\prime}}$ から, 式 (3)において二点間距離が十分に大き い場合に相関係数 $\rho$ を 0 として $\sigma_{Z}$ を求め, $\rho$ を二点間距離の 関数として推定することが可能である.しかしながら, 図 6 におけ 
(a) EW

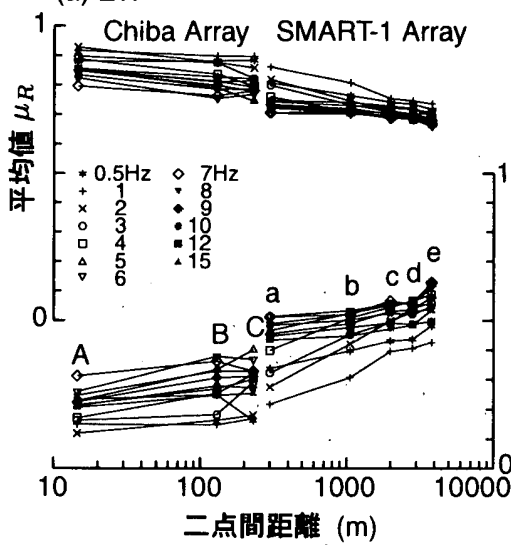

(b) NS

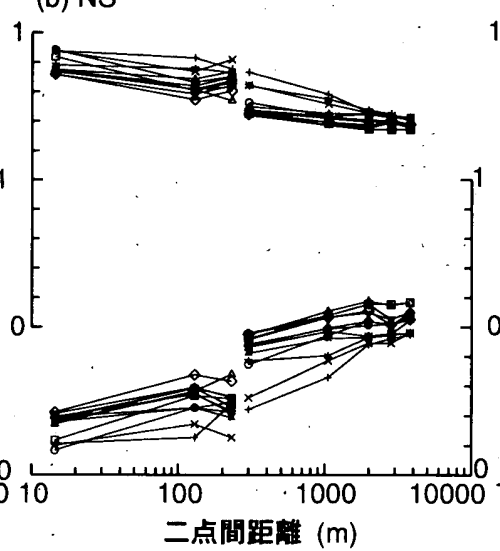

(c) UD

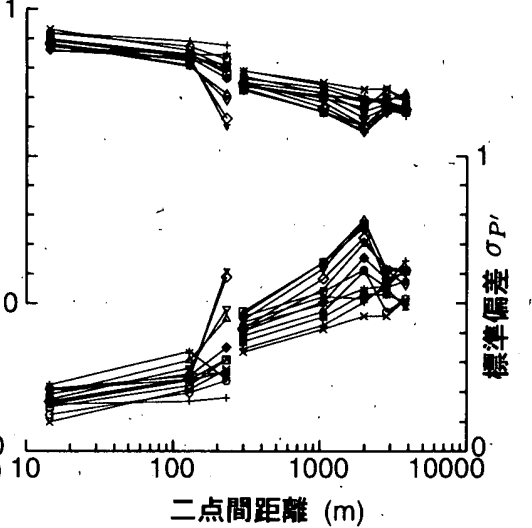

図 6 隇衰比 $h=0.05$ の場合の加速度応答スペクトル比の平均值 $\mu_{R}$, 標準偏差 $\sigma_{P^{\prime}}$ と二点間距離の関係, (a) EW 成分, (b) NS 成 分, (c) UD 成分

表 1 千葉アレーデータベースにおける二点間距離で分けたグルー プごとの応答スペクトル比のデー夕数

\begin{tabular}{|c|c|c|c|c|c|c|}
\hline \multirow{2}{*}{$\begin{array}{l}\text { グル } \\
-フ ゚\end{array}$} & \multicolumn{3}{|c|}{ 二点間距離 ${ }^{\prime} L(\mathrm{~m})$} & \multicolumn{3}{|c|}{ 比のデータ数 } \\
\hline & & 囲 & 平均 & EW & NS & UD \\
\hline $\mathrm{A}$ & $0<$ & $L \leq 40$ & 14.4 & 900 & 900 & 900 \\
\hline B & $40<$ & $L \leq 160$ & 129.3 & 617 & 617 & 617 \\
\hline C & $160<$ & $L$ & 230.3 & 252 & 252 & 252 \\
\hline 計 & & & & 1,769 & 1,769 & 1,769 \\
\hline
\end{tabular}

表 2 SMART-1アレーデータベースにおける二点間距離で分け たグループごとの応答スペクトル比のデータ数

\begin{tabular}{|c|c|c|c|c|c|}
\hline \multirow{2}{*}{$\begin{array}{l}\text { グル } \\
- \text { プ }\end{array}$} & \multicolumn{2}{|c|}{ 二点間距離 $L(\mathrm{~m})$} & \multicolumn{3}{|c|}{ 比のデー夕数 } \\
\hline & 範囲 & 平均 & EW & NS & UD \\
\hline $\mathrm{a}$ & $0<L \leq 650$ & 299.2 & 1,368 & 1,389 & 1,357 \\
\hline $\mathrm{b}$ & $650<L \leq 1,600$ & 1055.0 & 3,628 & 3,628 & 3,583 \\
\hline c & $1,600<L \leq 2,400$ & 1988.5 & 3,803 & 3,777 & 3,787 \\
\hline$d$ & $2,400<L \leq 3,200$ & 2826.1 & 1,315 & 1,297 & 1,305 \\
\hline $\mathrm{e}$ & $3,200<L$ & 3809.9 & 571 & 563 & 571 \\
\hline 計 & & & 10,685 & 10,654 & 10,603 \\
\hline
\end{tabular}

る $\sigma_{P^{\prime}}$ が大きな二点間距離に対して一定值に明らかに漸近してい ると見做すには少し問題がある。実際, 前報における最大加速度に 対する著者らの同様の検討において，その比の標準偏差 $\sigma_{P^{\prime}}$ を式 (2)(3)によって良く近似できたが, 一方で, 標準偏差 $\sigma_{Z}$ と相関 係数 $\rho$ を一意に精度良く分離して評価するには至っていない11). 本研究における応答スペクトルの場合においても相関係数 $\rho$ を分 離し，これと二点間距離の関係を作図することは現状では問題が あると考えられる。 今後の問題点としたい。

図 6 の, 互いによく似た形状の水平二成分について着目すると, 0.5 2 $\mathrm{Hz}$ 程度の低振動数で比較的小さい散布度, $5 \sim 7 \mathrm{~Hz}$ の振 動数で大きい散布度を示すことがわかる。そして，二点間距離の 変化に対して，この大小関係が大きく入机替わることはない。な お, 水平成分の標準偏差 $\sigma_{P^{\prime}}$ の最小值は千葉アレーA グループ の NS（3Hz）における 0.084 , また, 最大值は SMART-1 アレー e グループの $\mathrm{EW}, 7 \mathrm{~Hz}$ における 0.63 である。鉛直成分の場合で も，水平二成分の場合と同じような傾向を示している。
ところで, 応答スペクトル比が半区間对数正規分布に従う場合 には，その標準偏差 $\sigma_{P^{\prime}}$ と平均值 $\mu_{R}$ は式 (4) で示される関数 関係にある。図 7 は, 千葉アレーと SMART-1 アレーにおける加 速度応答スペクトル比（減衰比 $h=0.05, \mathrm{EW}$ 成分）の平均値 $\mu_{R}$ と標準偏差 $\sigma_{P^{\prime}}$ の関係を示したものである．図中の実線が式 (4) の関係を示す. 著者らは, 最大加速度の場合にこの関係がよく満た されることを示しているが, 図 7 から応答スペクトルの場合にお いてもこの関係がよく満だされるこがわかる。

\section{2 振動数と減衰比の影響}

図 8 に千葉アレーA，B，Cグループ, SMART-1 アレー a, c, e グループの加速度応答スペクトル比 (減衰比 $0.05, \mathrm{EW}$ 成分) の平均值 $\mu_{R}$ と標準偏差 $\sigma_{P^{\prime}}$ の振動数との関係を示す.

各グループごとの平均値 $\mu_{R}$ と標準偏差 $\sigma_{P^{\prime}}$ の全体的な形状 に着目すると, 二つのアレーのすべてのグループで同じょうな形 状を示しており，標集偏差 $\sigma_{P^{\prime}}$ の場合には $1,2 \mathrm{~Hz}$ 付近の極小 值と 5 7 $\mathrm{Hz}$ 付近の極大値, 平均值 $\mu_{R}$ の場合, $1,2 \mathrm{~Hz}$ 付近 の極大值, 5 7 $\mathrm{Hz}$ 付近の極小值で特徽付けられる.

図 9 は本解析で用いた SMART-1 アレー記録から C00 観測点 の記録が存在する 20 地震の $\mathrm{EW}$ 成分, 減衰比 0.05 の加速度応 答スペクトルを重ね書きしたものである。図 9 に見るように，そ れぞれの加速度応答スペクトルはマグニチュードに応じたスペク トル形状を示しているが， 5 7 Hzに極大值を持つ地震記録が多 いことがわかる。また，千葉アレーにおいても同様の傾向が見ら れることから, 地震動の卓越振動数の周辺で加速度応答スペクト ル比のばらつきが大きくなることも考えられる。ただし，マグニ チュードや震央距離などの地震諸元は応答スペクトル比の散布度 に対して単調增加, 減少のような単純な影響を与えるわけではな いこと ${ }^{13)}$ ，また，地震諸元の影響だけでなく地盤の増幅特性の影 響についても考察する必要があることなどの理由から,このメカ ニズムを明らかにするためには，地盤条件の異なった他のアレーに おける，広範囲のマグニチュードの地震記録の統計解析が今後必要 であると考えられる。

図 10 は, 減衰比 $h$ が加速度応答スペクトル比の平均值 $\mu_{R}$ と .標準偏差 $\sigma_{P^{\prime}}$ に与える影響を示したものである.この図から，検 討を行った $h=0.01$ - 0.2 までの広い範囲の減衰比の対数の増加に 対して, 平均值 $\mu_{R}$ と標準偏差 $\sigma_{P^{\prime}}$ はほほ直線的にそれぞれ增 加, 隇少することがわかる。たたし，この変化量は二点間距離や振 


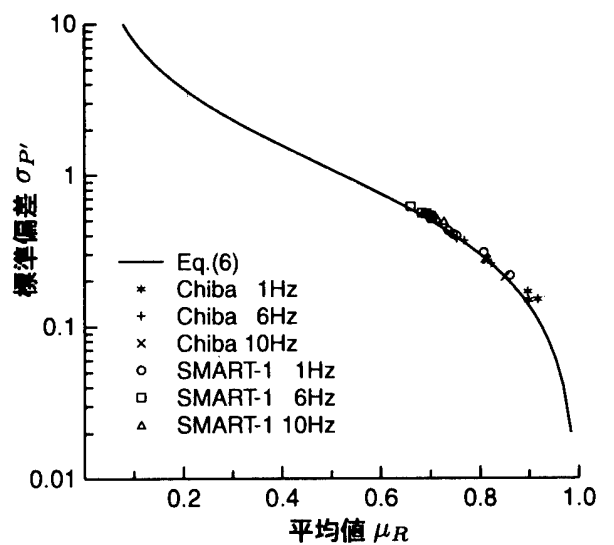

図 7 加速度応答スペクトル比の平均値 $\mu_{R}$ と標準偏差 $\sigma_{P^{\prime}}$ の 関係（減衰比 $h=0.05, \mathrm{EW}$ 成分）

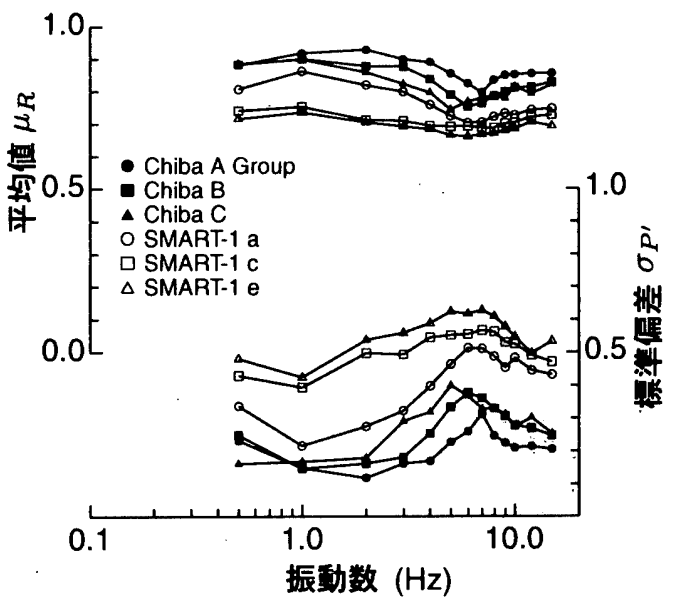

図 8 加速度応答スペクトル比の平均値 $\mu_{R}$, 標準偏差 $\sigma_{P^{\prime}}$ と振 動数の関係（減衰比 $h=0.05, \mathrm{EW}$ 成分）

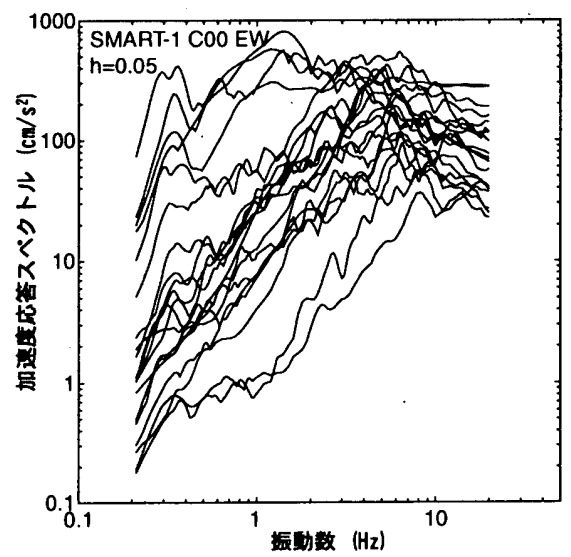

図 9 SMART-1 アレーの C00 観測点における 20 地震の加速 度応答スペクトル（EW 成分， $h=0.05 ）$

動数が与える影響に比べて小さい。また，減衰比が加速度応答ス ペクトル比の分布に与える影響は，二点間距離の各グループのそ れぞれに対して成り立つものであり，加速度応答スペクトルの非空 間的な確率分布の性質を表している。

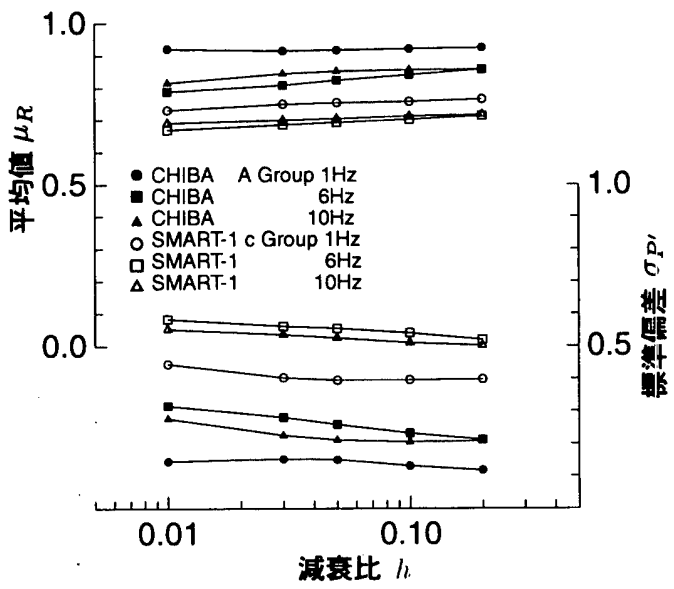

図 10 加速度応答スペクトル比の平均値 $\mu_{R}$, 標準偏差 $\sigma_{P^{\prime}}$ と 減衰比 $h$ の関係 (千葉アレーA グループ, SMART-1 アレー c グループ，EW 成分)

\section{6 加速度応答スペクトル比の確率密度関数と\%位值 6.1 確率密度関数}

図 11，図 12 はそれぞれ，千葉アレーと SMART-1 アレーにお ける，減衰比 $h=0.05$ に対する $\mathrm{EW}$ 成分の加速度応答スペクト ル比の確率密度関数を示したものである. 図中，○，口などの記号 付きの線は発生頻度から求めた確率密度関数を示してい弓。 また， 推定した標準偏差 $\sigma_{P^{\prime}}$ を式 (2)に代入して求めた半区間对数正規 分布の確率密度関数を, 発生頻度加求めた確率密度関数と同種 の線で示している。発生頻度による確率密度関数は, $0<R \leq 1$ の範囲を 20 等分して算定した．示した三つの振動数 $1 \mathrm{H} / \mathrm{z}, 6 \mathrm{~Hz}$, $10 \mathrm{~Hz}$ のうち, $1 \mathrm{~Hz}, 6 \mathrm{~Hz}$ はそれぞれ，標準偏差 $\sigma_{P^{\prime}}$ の極小値, 極大値を与える振動数にほほ対応している(図 8 参照).

発生頻度から求めた確率密度関数を見ると, 二点間距離が小さ い千葉アレーにおける $1 \mathrm{~Hz}$ の場合には三うのグループともに 1 に 近いスペクトル比を示す確率が高く，小さなスペクトル比を与える 確率は急速に減少する。これに対して $6 \mathrm{~Hz}, 10 \mathrm{~Hz}$ の場合には， 最頻值が 0.9 0.8 程度を示し，また， 0.5 程度の応答スペクトル比 を示す確率も認められるように変化していることがわかる。

発生頻度から求めた確率密度関数と半区間対数正規分布の確率 密度関数を比較すると, 半区間対数正規分布の確率密度関数は, A グループの $1 \mathrm{~Hz}$ の場合に大きい加速度応答スペクトル比を与える 確率を過小評価する傾向を示しているものの，その他のグループ や， $6 \mathrm{~Hz}, 10 \mathrm{~Hz}$ の場合などでは発生頻度から求めた確率密度関 数をよく近似するものとなっていることがわかる。

SMART-1 アレーの場合には，千葉アレーよりも二点間距離が大 きいことを反映して，0.5以下のスペクトル比をとる確率は千葉ア レ一の場合と比べてより大きい值を示す。また，これに対応して大 きいスペクトル比を示す確率が低隇するため, 確率密度関数は明瞭 な最頻值を示さない平坦な形状に変化している，なお，SMART-1 アレーにおいても，振動数の変化による確率密度関数の変化が顕 著であること, 発生頻度による確率密度関数が半区間対数正規分 布でよく近似されることなどは千葉アレーの場合と同様である.

\section{$6.2 \%$ 位值}

ある確率変数 $X$ とその対数值 $Z$ の二つの確率分布における \%位值は，単にその対数・指数を求めるだけで相互の変換が可能で ある。このため, 対数正規分布に近似される確率分布を検討する 

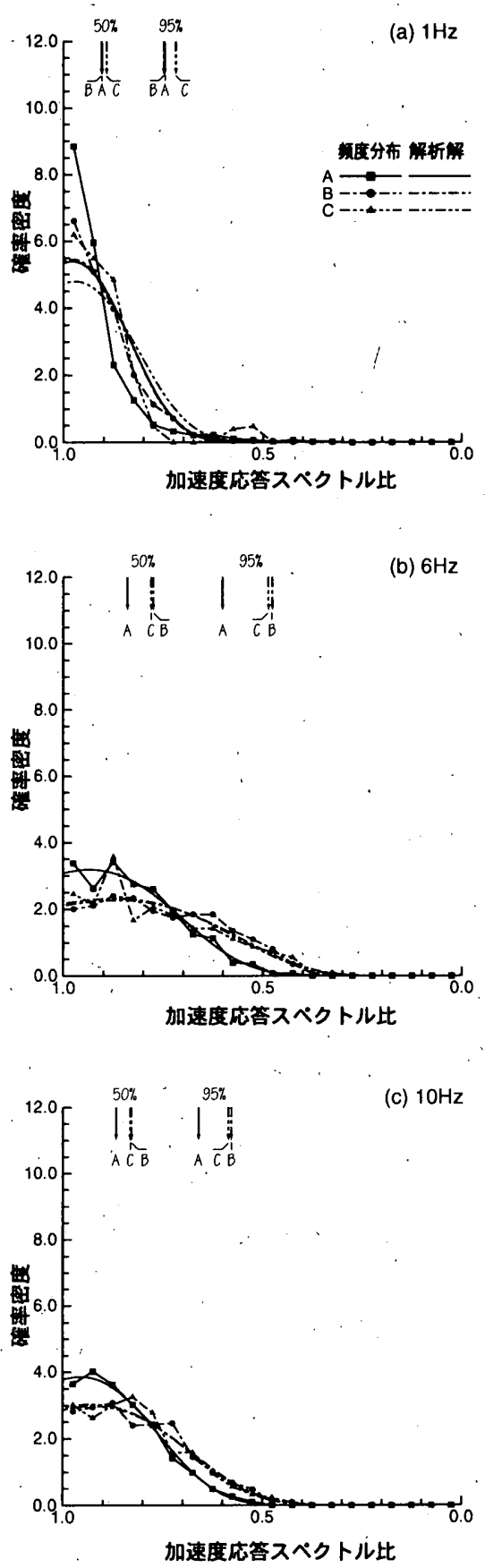

図 11 千葉アレーにおける加速度応答スペクトル比の確率密度 関数

上では有効な指標である。本研究では, 加速度応答スペクトル比 の代表值として $50 \%$ 位値, また, 危険率を $5 \%$ とした場合に加速度 応答スペクトル比の生じ得る最小值と見做すことができる95\%位 值を式 (5)に基づいて算定した.

得られた\%位值を図 11 , 図 12 に各グループの確率密度関数と 同種の線の矢印で示寸．図 11 の千葉アレーでは, $1 \mathrm{~Hz}$ の場合は 三つのグループで顕著な違いは認められず，50\%位值は 0.9 程度， $95 \%$ 位值は 0.7 程度を示している。 また, 比較的大きい散布度を示 す $6 \mathrm{~Hz}$ の場合には, 二点間距離が $40 \mathrm{~m}$ 以上の $\mathrm{B}, \mathrm{C}$ グループ における $50 \%$ 位值は 0.78 程度，95\%位值は 0.48 程度である。こ れらのことから, 千葉アレレのように二点間距離が数十一数百 $\mathrm{m}$
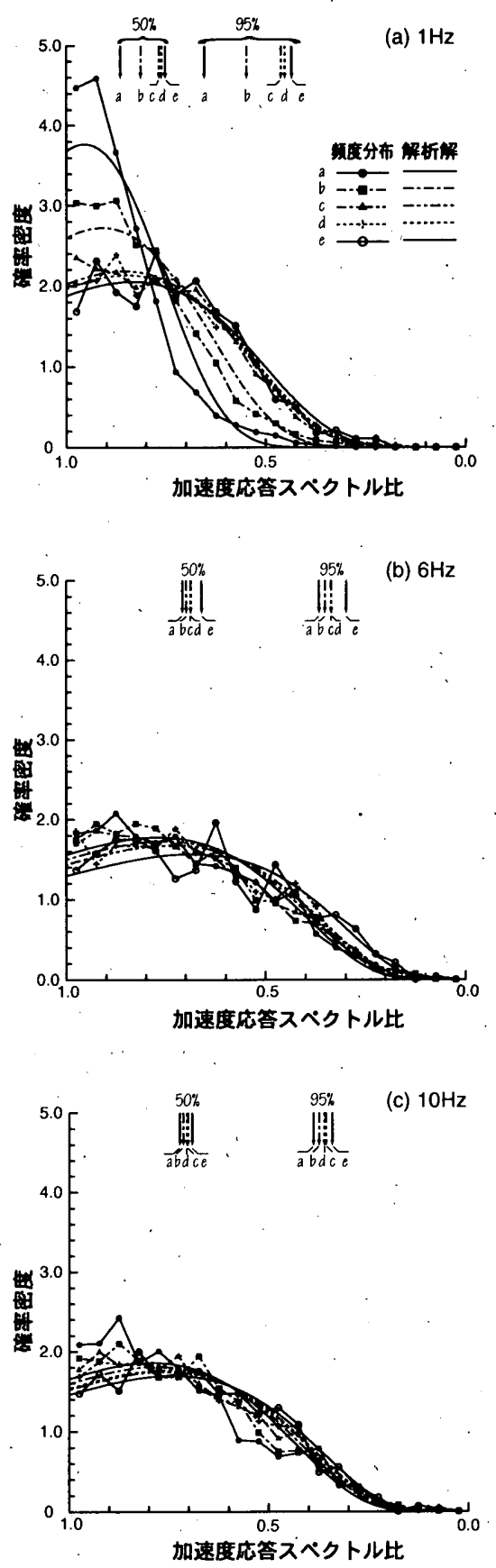

図 12 SMART-1 アレーにおける加速度応答スペクトル比の確率 密度関数

の範囲にある場合には，応答スペクトルの散布度が比較的小さい 振動数带域に対しては，50\%の確率で 0.9 - 1.1 倍程度, 最大でも (95\%の確率で) 0.7 - 1.4 倍程度の分布範囲にあることを想定すれ ばよく，また，散布度の大きい振動数帯域においても50\%の確率 で 0.8 - 1.25 倍程度, 最大で 0.5 2 倍, すなわち「倍半分」程度 の分布範囲を想定すればよいと言える。

図 12 の SMART-1 アレーの場合には，千葉アレーよりも大き い散布度を示すことに対応して $50 \%$ ，95\%位值はより小さい值を 示す．まず, $1 \mathrm{~Hz}$ の場合には a, b グループと他のグループで明暸 な違いがあり，a グループの 50\%位值，95\%位值がそれぞれ，0.85， 0.65 程度, b グループではそれぞれ $0.8,0.55$ 程度を示している. 
また，c，d，e グループでは顕著な違いは認められず，50\%位值， 95\%位值はそれぞれ，0.75，0.45 程度である。これに対して $6 \mathrm{~Hz}$, $10 \mathrm{~Hz}$ の場合には, 二点間距離の違いによる影響は小さく, 全ての グループの 50\%位值，95\%位值がそれぞれ，0.65〜0.7，0.3〜0.35 程度の範囲にある. 従って, 加速度応答スペクトルの散布度が比較 的小さい振動数帯域に対しては, 二点間距離が $1 \mathrm{~km}$ 程度以内の 場合（b グループ）では，50\%の確率で 0.8 1.25 倍程度, 最大で も $0.55 \sim 1.8$ 倍程度, 数 $\mathrm{km}$ 程度離れた二点では多少の距離の違 いにはあまりこだわらずに，50\%の確率で $0.75 １ .3$ 倍程度，最大 で 0.45－2.2 倍程度の分布範囲を想定すればよいと言える。一方, 大きい散布度を示す振動数帯域では二点間距離の違いにあまりこ だわる必要はないが, 50\%の確率で 0.7 1.4 倍程度, 最大で 0.35 一 3 倍程度の, より広い分布範囲を想定する必要がある。

\section{7 結論}

本研究では応答スペクトルの空間的な確率分布に着目し，応答 スペクトルの比（応答スペクトル比）を用いて，二点間で生じる応 答スペクトルの差異について検討した。 まず, 最大加速度の空間的 な確率分布をを評価するために著者らが展開した半区間対数正規分 布モデルについて簡単に説明した。次に, 千葉アレー, SMART-1 アレーにおける観測記録を用いて, 振動数, 隇衰比を变えて応答 スペクトル比を求めた。 そして, 応答スペクトル比の平均值 $\mu_{R}$, 標準偏差 $\sigma_{P^{\prime}}$, 確率密度関数, $50,95 \%$ 位值を算定し, これらの 結果に基づいて，以下の点を指摘した。

1. 加速度応答スペクトル比の平均値 $\mu_{R}$ と標準偏差 $\sigma_{P^{\prime}}$ は振 動方向, 振動数に拘わらずに, 二点間距離の増加に従ってそれ ぞ机減少, 増加する。そして, この傾向は条件が大きく異なる 千葉アレー, SMART-1 アレーの二つのアレーで共通であり, ほほ連続的な関係を示した。

2. 加速度応答スペクトル比は半区間対数正規分布に基づく標準 偏差 $\sigma_{P^{\prime}}$ と平均值 $\mu_{R}$ の関係式 (4) をよく满足する.

3. 両アレーにおける加速度応答スペクトル比の標準偏差 $\sigma_{P^{\prime}}$ は 二点間距離の違いに拘わらず, $1,2 \mathrm{~Hz}$ 付近の極小值と 5 7 $\mathrm{Hz}$ 付近の極大值で特徴付けられる形状を示す。また, これに 対応して平均值 $\mu_{R}$ は $1,2 \mathrm{~Hz}$ 付近の極大値, $5 \sim 7 \mathrm{~Hz}$ 付 近の極小值を示す.

4. 加速度応答スペクトル比の平均值 $\mu_{R}$ と標準偏差 $\sigma_{P^{\prime}}$ は減 衰比の対数の増加に対して，ほほ直線的にそれぞれ增加, 減少 する，ただし，この変化量は二点間距離や振動数による影響に 比べて小さい。

5. 加速度応答スペクトル比の確率密度関数は半区間対数正規分 布によってよく近似することができる。

6. 上記 $1 ， 3$ に関連して, 千葉アレーの場合（二点間距離が数十 一数百 $\mathrm{m}$ ) では, 加速度応答スペクトルは散布度が比較的小 さい $1,2 \mathrm{~Hz}$ において, $50 \%$ の確率で 0.9 - 1.1 倍程度, 最 大 (95\%位值) で 0.7 1.4 倍程度の範囲に分布する.また, 散布度の大きい 5 7 Hz の振動数帯域では $50 \%$ の確率で 0.8 －1.25 倍程度, 最大で 0.5 - 倍程度の範囲に分布する。

7. SMART-1 アレーの場合, 散布度が比較的小さい $1,2 \mathrm{~Hz}$ の振 動数に対して, 二点間距離が $1 \mathrm{~km}$ 程度の場合 (b グループ) では, $50 \%$ の確率で 0.8 - 1.25 倍程度, 最大で 0.55 - 1.8 倍程 度, 数 $\mathrm{km}$ 程度離れた二点では多少の距離の違いにはあまり 拘らずに，50\%の確率で 0.75〜1.3 倍程度，最大で 0.45 2.2
倍程度の範囲に分布する.また，散布度の大きい振動数帯域で は二点間距離の違いによる影響は小さく, $50 \%$ の確率で 0.7 1.4 倍程度, 最大では $0.35 \sim 3$ 倍程度の範囲に分布する。

謝辞 本研究では，震災予防協会によるアレーデータベースに収 録された東京大学生産技術研究所によるアレー観測記録, 並びに SMART-1 アレーにおけるアレー観測記録を用いました。本研究の 数値計算の一部は Shailendra Sharma 氏（当時埼玉大学理工学研 究科）によるものです。関係各位に厚くお礼申し上げます。

\section{参考文献}

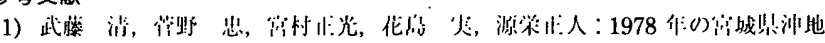

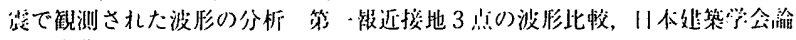

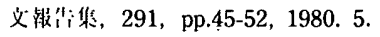

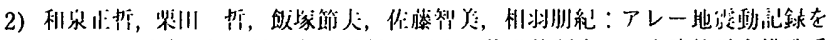

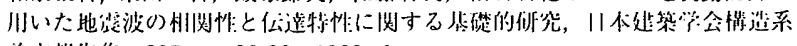

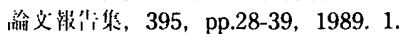

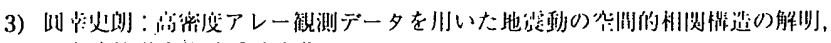

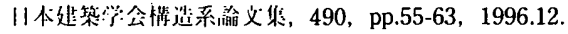

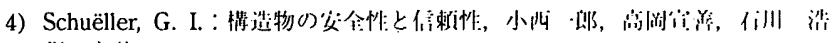
议, 九婇, 1984.

5) Boore, D. M., Joyner, W. B., Oliver, A. A. and Page, R. A. : Peak: acceleration, velocity, and displacememt from strong-motion records, Bull. Seism. Soc. Am., 70, 1, pp.305-321, 1980. 2.

6) Campbell, K. W. : Near-source attenuation of peak horizontal acceleration, Bull. Seism. Soc. Am., 71, 6, pp.2039-2070, 1981. 12.

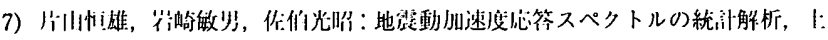
小学会渭文集, No.275, pp.29-40，1978. 7.

8) McGuire, R. K. : Seismic design spectra and mapping procedures using hazard analysis based directly on csillator response, Earthquake Engng. Struct. Dyn., 5, pp.211-234, 1977.

9) Spanos, P-T. D.: Response spectra of evolutionary earthquake models, 7th WCEE, 2, pp.387-390, 1980. 9.

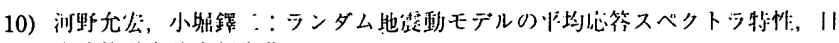

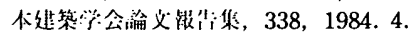

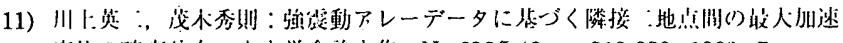

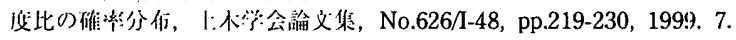

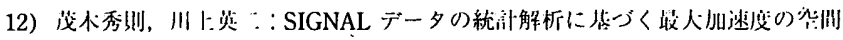

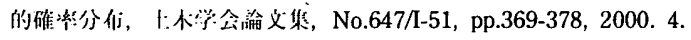

13) Kawakami, H. and Sharma, S.: Statistical study of spatial variation of response spectrum using free field records of dense strong motion arrays, Earthquaké Engng. Struct. Dyn., 28, pp.1273-1294, 1999. 11.

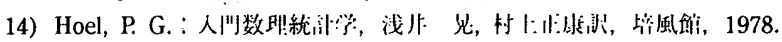

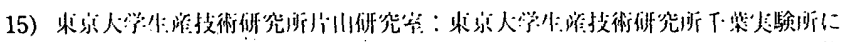

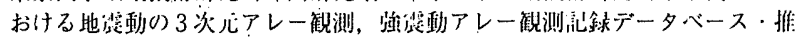

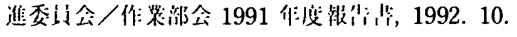

16) Bolt, B. A., Loh, C. H., Penzien, J., Tsai, Y. B. and Yeh, Y. T.: : Preliminary report on the SMART-1 strong motion array in Taiwan, Report No.UCB/EERC-82/13, Earthquake Engineering Research Center, University of California, Berkeley, 1982. 8.

17) Oliveira, C. S. and Penzien, J.:Spatial variation of seismic grourid motions based on SMART-1 array data, Proceedings of the Trilateral SeminarWorkshop on Lifeline Earthquake Engineering, Taipei, Taiwan, pp.59-75, 1985. 11 .

18) Loh, C-H. : Analysis of the spatial variation of seismic waves and ground movements from SMART-1 array data, Earthquake Eng. Struct. Dyn., 13, pp.561-581, 1985. 9.

19) Figueras, S., Roca, A., Goula, X: and Blàzquez, R.:Larger soil amplification for stronger ground motion from SMART-1 records, 10th WCEE, 2, pp.1043-1048, 1992.

20) SM-TAI04 磁メテーブ添付设料:

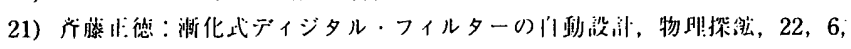
pp.240-263, 1978. 8.

(2001年 3 月 22 日原稿受理, 2001 年 9 月14日採用決定) 